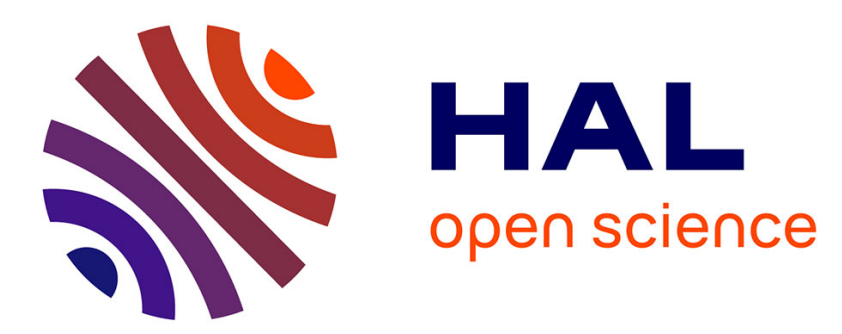

\title{
A metrics-based approach to preparing sustainable membranes: application to ultrafiltration
}

Flavie Prézélus, Dihia Chabni, Ligia Barna, Christelle Guigui, Jean-Christophe Remigy

\section{- To cite this version:}

Flavie Prézélus, Dihia Chabni, Ligia Barna, Christelle Guigui, Jean-Christophe Remigy. A metricsbased approach to preparing sustainable membranes: application to ultrafiltration. Green Chemistry, 2019, 21 (16), pp.4457-4469. 10.1039/c9gc01178a . hal-02295325

\section{HAL Id: hal-02295325 \\ https://hal.science/hal-02295325}

Submitted on 24 Sep 2019

HAL is a multi-disciplinary open access archive for the deposit and dissemination of scientific research documents, whether they are published or not. The documents may come from teaching and research institutions in France or abroad, or from public or private research centers.
L'archive ouverte pluridisciplinaire HAL, est destinée au dépôt et à la diffusion de documents scientifiques de niveau recherche, publiés ou non, émanant des établissements d'enseignement et de recherche français ou étrangers, des laboratoires publics ou privés. 


\section{OATAO \\ Open Archive Toulouse Archive Ouverte}

\section{Open Archive Toulouse Archive Ouverte (OATAO)}

OATAO is an open access repository that collects the work of Toulouse researchers and makes it freely available over the web where possible

This is an author's version published in: http://oatao.univ-toulouse.fr/ 24253

Official URL: https://doi.org/10.1039/c9gc01178a

\section{To cite this version:}

Prézélus, Flavie and Remigy, Jean-Christophe $\rightleftharpoons$ A metrics-based approach to preparing sustainable membranes: application to ultrafiltration. (2019) Green Chemistry, 21 (16). 4457-4469. ISSN 1463-9262

Any correspondence concerning this service should be sent to the repository administrator: tech-oatao@listes-diff.inp-toulouse.fr 


\title{
A metrics-based approach to preparing sustainable membranes: application to ultrafiltration
}

\author{
Flavie Prézélus, (DD a,b Dihia Chabni, ${ }^{a}$ Ligia Barna, (D) ${ }^{\mathrm{b}}$ Christelle Guigui ${ }^{\mathrm{b}}$ and \\ Jean-Christophe Remigy (D) *a
}

\begin{abstract}
The purpose of the research is to make a first step towards rationalizing green polymeric membrane preparation. A holistic methodological approach based on metrics that consider technical, environmental, health and safety issues have been suggested to assess sustainability of membrane preparation. Metrics have been applied to solvent substitution in a non-solvent induced phase separation process. The flammability hazard of three shortlisted alternative solvents has substituted the reprotoxicity hazard of common solvents. The ultrafiltration cellulose diacetate membranes prepared with methyl lactate as solvent have a greater renewable intensity and require a lower number of solvents for their preparation. Trade-offs between use of resources (polymer, solvent, energy...) and membrane properties are inevitable. Further socio-economic, risk and life cycle analysis are crucial to fully integrate ecodesign in membrane preparation.
\end{abstract}

\section{Introduction}

Membrane technology is well-established in industrial processes as it offers both technical and sustainable performances: high selectivity of specific compounds, excellent waste and energy efficiency, ease of operation and maintenance, simple scale-up and control and good stability. ${ }^{1,2}$ One membrane technique is ultrafiltration used, for instance, to separate particulates and pathogens from raw water for drinking water applications or to process proteins in the dairy industry. Mild thermal and chemical operating conditions in water treatment favour polymeric membranes over more expensive ceramic ones.

Most commercialized polymeric membranes are prepared via non-solvent induced phase separation (NIPS). ${ }^{3}$ A polymer is first dissolved in a solvent usually with an additive. Adding inorganic salts such as lithium chloride (LiCl) or polymers (PEG, PVP) have shown to improve membrane permeability and retention. ${ }^{4,5}$ The polymer solution is then cast on a planar support or extruded as a hollow fibre and then immersed in a non-solvent in which it separates into two phases: a polymer rich phase that solidifies into the membrane structure and a polymer lean phase that is washed away and gives the pores. ${ }^{6-9}$ The non-solvent is often water as it does not solubilize common used polymers, is inexpensive and easy to handle on an industrial scale. Further steps are membrane rinsing and module preparation. During coagulation and rinsing the polymer lean

\footnotetext{
${ }^{a}$ Laboratoire de Génie Chimique, Université de Toulouse, CNRS, INPT, UPS, Toulouse, France.E-mail: remigy@chimie.ups-tlse.fr

${ }^{b}$ TBI, Université de Toulouse, CNRS, INRA, INSA, Toulouse, France
}

phase (mainly solvent and additive) is mixed with water and is either recycled or discharged in the sewage network.

Research in membrane preparation has integrated sustainability concerns in response to global concern about preserving finite resources for future generations. ${ }^{10}$ Focus in the literature is mainly on the solvents' toxicity. Three of the most common solvents used in membrane preparation ( $N$-methyl-2pyrrolidone (NMP), $N, N$-dimethylacetamide (DMA) and $N, N$-dimethylformamide (DMF)) are indeed identified by the European REACH Regulation as substances of very high concern for their potential reproductive toxicity. ${ }^{11}$ Furthermore, the initial amount of solvent is entirely found in wastewater after coagulation and rinsing. Razali et al. estimate that this wastewater represents more than $95 \%$ of the total waste produced during membrane preparation. ${ }^{12}$ Figoli et al. ${ }^{13}$ report on the beginning stages of solvent substitution in membrane preparation with examples of less or non-toxic solvents. Another approach that is also at an early stage of research is to eliminate solvent toxicity by using an aqueous polymer solution and subjecting it to a temperature induced phase separation (TIPS). ${ }^{14}$

Searching for and selecting green solvents is a global issue. ${ }^{15,16}$ CHEM21 developed a methodology to rank solvents according to environmental, health and safety criteria aligned with the United Nation's Global Harmonized System (GHS) and European regulations. ${ }^{17}$ The resulting solvent selection guide is based on guides previously published by pharmaceutical companies ${ }^{18-23}$ and includes newer solvents such as bioderived solvents. ${ }^{24}$ Tobiszewski et al. ${ }^{25}$ rank solvents within clusters according to toxicology and hazard parameters.

Besides the solvent issue, reducing the use of petroleumbased chemicals is another aspect of sustainability. Growing 
attention is for example given to biosourced polymers since carbon composing these polymers originates from atmospheric carbon dioxide and is released back into the atmosphere whenever the polymers are incinerated: no additional carbon dioxide is emitted in this case. ${ }^{26}$ Since Dobry's treatment of cellulose esters ${ }^{27}$ and Loeb and Sourirajan's preparation of asymetric membranes ${ }^{28}$ membranes prepared with cellulose acetate (CA) offer a bio-sourced alternative to other conventional membranes prepared with petrochemical polyether sulfone (PES), polysulfone or polyvinylidene difluoride. ${ }^{29}$ CA membranes were first developed for desalination of water by reverse osmosis ${ }^{28,30}$ and are now found in other applications such as hemodialysis or drinking water treament. ${ }^{31,32}$ As regards water treatment applications, CA membranes are cheap, easily available and highly resistant to fouling. ${ }^{33}$ Cellulose triacetate and diacetate (CTA and CDA respectively) are synthesized from cellulose, the most abundant organic polymer on Earth and industrially extracted from wood pulp or cotton. $^{34}$ Krishna Manda et al. ${ }^{35}$ calculated that CA has a slightly better environmental profile than PES for most impact categories (climate change, human toxicity, marine and freshwater ecotoxicity...). Only the production and disposal of both polymers have been considered; the production and operation of the two associated membranes have been simplistically taken as equal to one another.

Substituting toxic solvents and using renewable feedstocks are only two sustainability improvements and therefore do not fully address the twelve principles of green chemistry as listed by Anastas and Warner. ${ }^{36}$ Their framework sets out a broad view on the design and development of greener chemicals, materials and processes. Green metrics have been later developed to quantitatively evaluate sustainability. ${ }^{37-39}$ Interestingly, McElroy et al. ${ }^{40}$ suggest a holistic approach to metrics. The sustainability of chemical reactions are evaluated with a unified metrics toolkit. The aim of such an approach is to study the overall environmental footprint of a given system, thereby taking into account burdens that shift from one subsystem to another or from one impact category to another.

To the best of our knowledge, no holistic approach to assessing sustainability in membrane preparation has been taken in the literature. In our study, metrics that consider technical, environmental, health and safety (EHS) issues are first presented and then applied to solvent substitution in the preparation of ultrafiltration membranes. Both CTA and CDA are tested as polymers. More specifically, Hansen solubility parameters (HSPs) and solubility trials are used for solvent screening. Flat sheet membranes are prepared with the selected solvents and their permeability and retention performances are assessed experimentally.

\section{Metrics for membrane preparation}

Membrane preparation is considered in 3 stages (see Table 1), each having specific metrics that allow to compare alternative solvents and their associated membranes. Hotspots such as
Table 1 Metrics tables relative to solvent substitution for membrane preparation

\begin{tabular}{|c|c|c|c|}
\hline Stage & Stage name & $\begin{array}{l}\text { Concerned process or } \\
\text { chemical composition }\end{array}$ & $\begin{array}{l}\text { Metrics } \\
\text { table }\end{array}$ \\
\hline \multirow[t]{2}{*}{ I } & Alternative solvent & Solvent & Table 2 \\
\hline & shortlisting & Solvent fabrication & Table 3 \\
\hline ii & Solubility trials & Polymer solution & Table 4 \\
\hline \multirow[t]{2}{*}{ iii } & Membrane & Membrane & Table 5 \\
\hline & preparation & Membrane fabrication & Table 3 \\
\hline
\end{tabular}

flammability or energy-intensive fabrication processes are highlighted to either eliminate a solvent from the screening process or take precautionary measures during scale-up. These metrics are relative and can be adapted to the intended application such as ultrafiltration in drinking water treatment, as opposed to absolute metrics solely based on threshold values. For example, there is no threshold value for energy use but rather a comparison to be made with other solvents' fabrication processes.

It is interesting to note that McElroy et $a l^{40}$ adopt a threecoloured flag system applied to their metrics as an attempt to alert on specific issues. Quantified ranges for each colour (green, amber and red) are however defined for only 3 metrics and the lack of justification suggests that these ranges result from an arbitrary choice. These omissions most certainly stem from the difficulty to apply the three-coloured flag system in a thorough and consistent manner. It is indeed very challenging to define meaningful threshold values for each colour, especially considering that thresholds may depend on the intended application or operational conditions. Such a visual aid also aims at putting emphasis on certain metrics rather than on others, which is inconsistent with our holistic approach according to which metrics are to be considered altogether. No visual aid has thus been integrated in our work.

During alternative solvent shortlisting (stage i in Table 1), the technical and EHS compatibility of the shortlisted solvents (Table 2) and their fabrication process (Table 3) are assessed. During solubility trials of stage ii, polymer solution parameters give information on the technical feasibility of membrane preparation with the associated alternative solvent (Table 4). If feasible, membranes are fabricated during stage iii. Either flat sheet membranes or hollow fibres can be prepared. Flat sheet membrane preparation can also be conducted as a feasibility study for hollow fibre preparation.

Technical membrane performances (Table 5) and eco-compatibility of the fabrication process (Table 3) are then studied.

The metrics can be transposed to polymer or additive substitution as well as to other membrane preparation processes (e.g. TIPS) provided several adjustements be made. For polymer substitution, water insolubility and solvent solubility are sought, whereas polymer volatility is irrelevant. The fabrication process of the polymer, instead that of the solvent, should be investigated. For a TIPS process, the polymer must be soluble in the solvent at high temperatures (generally 100-200 ${ }^{\circ} \mathrm{C}$ (ref. 41)) and insoluble at ambient temperature. 
Table 2 Metrics for the solvent

\begin{tabular}{|c|c|c|}
\hline Criterion & Parameter & Metric \\
\hline \multirow[t]{3}{*}{ Technical } & Solvency & $\begin{array}{l}\text { Relative energy difference } \\
\text { (solvent and polymer Hansen } \\
\text { solubility parameters) } \\
\text { Solubility in water }\end{array}$ \\
\hline & Stability & $\begin{array}{l}\text { Thermal decomposition } \\
\text { Chemical degradation }\end{array}$ \\
\hline & Volatility & $\begin{array}{l}\text { Vapour pressure } \\
\text { Boiling point }\end{array}$ \\
\hline \multirow[t]{6}{*}{ Safety } & Inflammability & Flash point \\
\hline & Other physical & Explosiveness \\
\hline & hazard & Self-reactivity \\
\hline & & Pyrophoricity \\
\hline & & Oxidizing \\
\hline & & Corrosivity \\
\hline \multirow[t]{8}{*}{ Health } & Acute toxicity & Acute toxicity estimate values \\
\hline & $\begin{array}{l}\text { Specific target } \\
\text { organ toxicity }\end{array}$ & $\begin{array}{l}\text { Single and repeated exposure } \\
\text { tests }\end{array}$ \\
\hline & Aspiration hazard & Aspiration hazard \\
\hline & or irritation & $\begin{array}{l}\text { Skin corrosion or irritation } \\
\text { Serious eye damage or eye } \\
\text { irritation }\end{array}$ \\
\hline & & $\begin{array}{l}\text { Respiratory or skin } \\
\text { sensitization }\end{array}$ \\
\hline & Carcinogenic, & Germ cell mutagenicity tests \\
\hline & mutagenic, & Carcinogenicity tests \\
\hline & reprotoxic & Reprotoxicity tests \\
\hline \multirow[t]{5}{*}{ Environmental } & Biodegradability & Ready biodegradability \\
\hline & Bioaccumulation & Bioconcentration factor \\
\hline & & $\begin{array}{l}\text { Octanol-water partition } \\
\text { coefficient }\end{array}$ \\
\hline & Ecotoxicity & Acute aquatic toxicity \\
\hline & & Chronic aquatic toxicity \\
\hline
\end{tabular}

For the NIPS process considered in this work, solvent miscibility in water must be sufficient to allow polymer coagulation upon contact of the polymer solution with the non-solvent (see Table 2). The solvent must also dissolve the polymer. Given the large number of existing solvents, screening methods based on the potential solvent solvency of the polymer are necessary to reduce the number of solubility trials to carry out. The relative energy difference (RED), calculated from HSPs, allows to select an appropriate solvent for a polymer ${ }^{42}$ (see section 3 ) and is often used in formulation for its simplicity of use and predictive quality. ${ }^{43}$ Solvent stability is a technical prerequisite for the solvent use: no thermal or chemical degradation (hydrolysis, oxidation, autoxidation) that could hamper coagulation should occur under the operational conditions of membrane preparation. Another solvent property considered is volatility.
Table 4 Metrics for the polymer solution

\begin{tabular}{lll}
\hline Criterion & Parameter & Metric \\
\hline Technical & Solvency & Polymer and additive dissolution \\
& Casting capacity & Viscosity \\
& Stability & Turbidity \\
& & Gel formation and crystallization
\end{tabular}

Table 5 Metrics for the membrane

\begin{tabular}{lll}
\hline Criterion & Parameter & Metric \\
\hline Technical & Productivity & Permeability \\
& Selectivity & Molecular weight cut-off \\
& Log removal values \\
& Integrity tests \\
& Mechanical resistance & Tensile stress \\
& Compaction pressure \\
& Chemical resistance & Ageing trials
\end{tabular}

High vapour pressure under operational conditions compels to take precautionary measures to reduce solvent exposure and protect workers' health and safety. EHS criteria in Table 2 are based on the hazards defined and classified by the GHS. ${ }^{44}$ Regional or national implementations of the GHS can also be used as reference (e.g. the European CLP Regulation). An ideal solvent does not present any hazard and thus does not have any associated H-statement. Should this not be the case, hazard categories reflect the hazard severity. A category 1 solvent has extremely flammable liquid and vapour, whereas a category 4 solvent is a combustible liquid. Being readily biodegradable and not bioaccumulating are two properties reducing the solvent's end-oflife environmental impact, in particular in aquatic environments.

A solvent's overall environmental footprint does not only rely on its intrinsic properties but also on the processes in which it is involved. Life Cycle Analysis (LCA) studies assess environmental impacts of all stages of a product's life from raw material extraction through manufacture, transportation, use and disposal or recycling. Such a comprehensive approach demands expertise, time, a lot of data and is more appropriate for a final assessment of the selected solvent. A more straightforward assessment can be made as a first approach with metrics suggested in Table 3. Intensity-based metrics evaluate the total input (e.g. renewably derivable input materials, reagents, solvents, catalysts, energy etc.) needed to prepare one

Table 3 Metrics for both solvent and membrane fabrication processes

\begin{tabular}{|c|c|c|}
\hline Criterion & Metric & Simplified metric \\
\hline \multirow[t]{7}{*}{ Environmental } & $\begin{array}{l}\text { Renewable intensity = mass renewable derivable material/ } \\
\text { product mass }\left(\mathrm{kg} \mathrm{kg}^{-1}\right)\end{array}$ & Number of renewably derivable feedstocks \\
\hline & \multirow[t]{2}{*}{ Process mass intensity $=$ total process mass/product mass $\left(\mathrm{kg} \mathrm{kg}^{-1}\right)$} & Number of reactions and separation steps \\
\hline & & Number of solvents (for membrane fabrication only) \\
\hline & \multirow[t]{3}{*}{ Energy intensity = process energy/product mass $\left(\mathrm{MJ} \mathrm{kg}^{-1}\right)$} & Operational conditions (temperature, pressure) \\
\hline & & Number of liquid streams to treat \\
\hline & & Number of solvents per liquid stream \\
\hline & Use of critical elements & - \\
\hline
\end{tabular}


unit mass of product. ${ }^{45,46}$ Alternatively, counting the number of reactions or noting the operational conditions (temperature, pressure) gives a first indication on the use of resources; numerous reactions under high temperatures and pressures to produce the solvent is likely to be more mass- and energy-intensive than a single-reaction process under ambient conditions. Furthermore, critical elements (rare earth metals, phosphate rock, cobalt...) used in the preparation process need to be indicated. According to the European Union, an element is critical when it is of high economic importance and if there are high supply risks, either due to limited abundance or geo-political issues. ${ }^{47}$ Table 3 should also be applied to the membrane fabrication process during stage iii.

In Tables 4 and 5, technical criteria classically encountered in membrane science are listed for polymer solutions and another. The partial or Hansen solubility parameters $\left(\delta_{\mathrm{d}}, \delta_{\mathrm{p}}, \delta_{\mathrm{h}}\right)$ of a chemical compound are the square root of the quotient of the respective intermolecular energy and the molar volume $(V)$ :

$$
\delta_{\mathrm{d}}=\sqrt{\frac{E_{\mathrm{d}}}{V}}, \delta_{\mathrm{p}}=\sqrt{\frac{E_{\mathrm{p}}}{V}}, \delta_{\mathrm{h}}=\sqrt{\frac{E_{\mathrm{h}}}{V}}
$$

A chemical compound can be represented by a dot in the $3 \mathrm{D}$ solubility space $\left(2 \delta_{\mathrm{d}}, \delta_{\mathrm{p}}, \delta_{\mathrm{h}}\right)$. Based on experimental solubility data, Hansen defines a solubility volume for a polymer within this $3 \mathrm{D}$ space. It is a sphere with centre $\left(\delta_{\mathrm{d}}\right.$ polymer, $\left.\delta_{\mathrm{p} \text { polymer }}, \delta_{\mathrm{h} \text { polymer }}\right)$ and radius $R_{0}$. Solvents with HSPs within the solubility sphere dissolve the polymer, whereas those outside do not. For polymer dissolution, the interaction polymer-solvent distance $R_{\mathrm{a}}$ must thus be inferior or equal to $R_{0}$ :

$$
R_{\mathrm{a}}=\sqrt{4\left(\delta_{\mathrm{d} \text { polymer }}-\delta_{\mathrm{d} \text { solvent }}\right)^{2}+\left(\delta_{\text {p polymer }}-\delta_{\text {p solvent }}\right)^{2}+\left(\delta_{\text {h polymer }}-\delta_{\text {h solvent }}\right)^{2}} \leq R_{0}
$$

membranes. Effective dissolution of the polymer and additive by the solvent is observed during solubility trials. To cast or spin membranes, the polymer solution must have a viscosity adapted for both appropriate mechanical strength and lowenergy pumping. On an industrial scale, temporary shutdowns may require the polymer solution to be stored. The absence of coagulation, gel formation or crystallization can be monitored by turbidity measurements or dynamic light scattering techniques. Once membranes are prepared, their technical performances are to be assessed (Table 5) and compared to the technical specifications of ultrafiltration and its process. For example, ageing trials based on accelerated ageing with the concentration per time of contact parameter $(c \times t$ parameter $)$ indicate to what extent chemicals used during cleaning sequences are compatible with the membrane material. ${ }^{48}$ The integrity of membranes can be checked with pressure hold tests or bubble tests. ${ }^{49}$

In what follows, the 3 -stage membrane preparation methodology in Table 1 is followed and metrics in Tables $2-5$ are applied. HSPs used for solvent shortlisting first need to be explained as well as the experimental setups of membrane preparation and characterization.

\section{Hansen solubility parameters (HSPs)}

Hansen considers three types of intermolecular interactions for the total cohesion energy $(E)$ of regular solutions: ${ }^{42}$

$$
E=E_{\mathrm{d}}+E_{\mathrm{p}}+E_{\mathrm{h}}
$$

where $E_{\mathrm{d}}$ is the energy from London dispersion forces, $E_{\mathrm{p}}$ is the energy from dipole-dipole forces (Debye and Keesom) and $E_{\mathrm{h}}$ is the energy from hydrogen-bonding forces. $E$ is equivalent to the latent heat of vaporization, a measure of the strength of attractive forces holding molecules together. During polymer dissolution, these interactions are overcome as the solvent surrounds polymer macromolecules thereby separating them one from
In other words, the relative energy difference (RED) must be inferior or equal to 1 :

$$
\mathrm{RED}=\frac{R_{\mathrm{a}}}{R_{0}} \leq 1
$$

Different HSP values for CA are available in Hansen's User's Handbook $^{50}$ (Table 6): each set of $\left(\delta_{\mathrm{d}}, \delta_{\mathrm{p}}, \delta_{\mathrm{h}}\right)$ values hold true for a given industrial polymer. Differences in HSP values may be explained by the specificities of each industrial polymer (i.e. degree of acetyl substitution, molecular weight, type and percent of impurities...). This information is unfortunately not detailed in the references, as shown in the second column of Table 6.

Polymer HSP values can be determined experimentally by carrying out solubility tests with solvents having known HSPs. However, the polymer solubility sphere radius $R_{0}$ depends on the solubility criteria predefined by the experimenter. Depending on the targeted application, it can range from a low degree of polymer swelling to complete dissolution in given operating conditions.

\section{Experimental}

\subsection{Materials}

\begin{tabular}{|c|c|c|c|c|c|}
\hline $\begin{array}{l}\text { Name as found } \\
\text { in User's } \\
\text { Handbook }\end{array}$ & Supplier & $\begin{array}{l}\delta_{\mathrm{d}} \\
(\mathrm{MPa})^{1 / 2}\end{array}$ & $\begin{array}{l}\delta_{\mathrm{p}} \\
(\mathrm{MPa})^{1 / 2}\end{array}$ & $\begin{array}{l}\delta_{\mathrm{h}} \\
(\mathrm{MPa})^{1 / 2}\end{array}$ & $\begin{array}{l}R_{0} \\
(\mathrm{MPa})^{1 / 2}\end{array}$ \\
\hline $\begin{array}{l}\text { Cellidora A, } \\
\text { Bayer }\end{array}$ & Bayer & 18.2 & 12.4 & 10.8 & 7.4 \\
\hline Cellulose acetate & $\mathrm{N} / \mathrm{A}^{a}$ & 16.9 & 16.3 & 3.7 & 13.7 \\
\hline Cellulose acetate & $\mathrm{N} / \mathrm{A}^{a}$ & 18.3 & 16.5 & 11.9 & 8.8 \\
\hline Cellulose acetate & $\mathrm{N} / \mathrm{A}^{a}$ & 14.9 & 7.1 & 11.1 & 12.4 \\
\hline
\end{tabular}

CTA (Eastman CA-436-80S, 43.6\% acetyl content) was kindly supplied by ABC Membranes (France). CDA (average $M_{\mathrm{n}} \sim$

Table 6 HSPs for CA in Hansen's User's Handbook ${ }^{50}$ 
$30000 \mathrm{Da}, 39.8 \%$ acetyl content) and $\mathrm{LiCl}(\geq 99 \%)$ were purchased from Sigma-Aldrich (USA). All three chemicals were desiccated at $120{ }^{\circ} \mathrm{C}$ during 15 minutes before use. Methyl lactate (99\%) was obtained from J\&K Scientific (China), ethyl lactate $(\geq 98 \%)$ kindly supplied by Galactic S.A. (Belgium) and triethyl phosphate (synthesis grade) purchased from Merck (USA). Dimethyl carbonate ( $\geq 99 \%)$, ethyl levulinate $(\geq 99 \%)$, gamma-valerolactone $(\geq 99 \%)$ and methyl levulinate $(\geq 98.0 \%)$ were purchased from Sigma-Aldrich. Polyethylene glycol (PEG, $200 \mathrm{kDa}$ ), sodium bisulfite and glycerol (laboratory reagent grade) were purchased from Sigma-Aldrich, Acros Organics (Belgium) and VWR International (USA), respectively. Ultrapure water $\left(T=23 \pm 2{ }^{\circ} \mathrm{C}\right)$ with a resistivity of $18 \mathrm{M} \Omega \mathrm{cm}$ was produced by a PURELAB Maxima unit (ELGA, UK).

\subsection{Solubility trials}

The HSPs of CDA and CTA were determined with the software HSPiP 5.0. ${ }^{50,51}$ based on the results of solubility trials (soluble or insoluble). The latter were carried out at $25{ }^{\circ} \mathrm{C}$ with a $12 \mathrm{wt} \%$ polymer solution under mechanical agitation for one week to achieve the solubility equilibrium. 21 well-defined solvents were chosen so as to cover a large area of the 3D solubility space. Blends of two miscible solvents were used to better define the sphere boundary. Solubility was visually qualified seeking clear solution; insoluble or swell polymer were classified as non soluble.

The same protocol was followed to test shortlisted alternative solvents for polymer dissolution. For $\mathrm{LiCl}$ dissolution trials, $1.2 \mathrm{wt} \%$ of the additive was blended with each alternative solvent.

\subsection{Flat sheet membrane preparation}

Polymer solutions were prepared with CDA as polymer and $\mathrm{LiCl}$ as additive. Either ethyl lactate or methyl lactate was used as solvent. LiCl was first dissolved in one solvent at $80{ }^{\circ} \mathrm{C}$ during $1 \mathrm{~h}$. The polymer was added gradually to the solventadditive solutions during $24 \mathrm{~h}$. The solutions were mechanically stirred at $300 \mathrm{rpm}$ and kept at $80^{\circ} \mathrm{C}$ during another $24 \mathrm{~h}$ for homogenization. The polymer solutions were cast on a glass plate at 80,70 or $60^{\circ} \mathrm{C}$ using a Gardner knife with a gap of $200 \mu \mathrm{m}$ and finally immersed in a coagulation bath (15 $\mathrm{v} / \mathrm{v} \%$ methyl lactate or glycerol in ultra-pure water) at $25^{\circ} \mathrm{C}$ for $1 \mathrm{~h}$. The subsequent flat sheet membranes were placed in an ultra-pure water bath for $3 \mathrm{~h}$. The water was renewed every hour to remove any residual solvent and additive. Flat sheet membranes were then stored in $10 \mathrm{~g} \mathrm{~L}^{-1}$ sodium bisulfite solutions.

\subsection{Membrane and polymer solution characterizations}

4.4.1. Viscosity measurement. The viscosity of polymer solutions were measured using a rheometer (Physica MCR 301, Anton Paar, Austria) equipped with a rotational cylinder measuring system.

4.4.2. Pure water permeability. Ultra-pure water permeability $\left(L_{\mathrm{p}}, \mathrm{L} \mathrm{h}^{-1} \mathrm{~m}^{-2} \mathrm{bar}^{-1}\right)$ at $20^{\circ} \mathrm{C}$ was measured using a dead-end set-up (Amicon cell) ${ }^{52}$ and determined as the slope of the following equation:

$$
J_{20{ }^{\circ} \mathrm{C}}=L_{\mathrm{p}, 20^{\circ} \mathrm{C}} \mathrm{TMP}
$$

where $J_{20^{\circ} \mathrm{C}}$ is the permeate flux at $20{ }^{\circ} \mathrm{C}\left(\mathrm{L} \mathrm{h}^{-1} \mathrm{~m}^{-2}\right)$ and TMP is the applied transmembrane pressure (bar). The effective membrane surface was $1.52 \times 10^{-3} \mathrm{~m}^{2}$. Before sampling, the permeate flux was left to stabilize $15 \mathrm{~min}$ at 1 bar.

4.4.3. PEG rejection. A $200 \mathrm{kDa}$ PEG solution of $1 \mathrm{~g} \mathrm{\textrm {L } ^ { - 1 }}$ was filtered with the same set-up as for pure water permeability. The stirring speed was $300 \mathrm{rpm}$ and the four applied TMPs were $0.2,0.4,0.6$ and 0.8 bar.

Retentate and permeate PEG samples were analyzed with a total organic carbon analyzer (TOC-L CSH, Shimadzu, Japan). The observed PEG retention $R_{\mathrm{obs}}$ is calculated by equation:

$$
R_{\mathrm{obs}}=1-\frac{C_{\mathrm{p}}}{C_{\mathrm{r}}}
$$

where $C_{\mathrm{p}}$ and $C_{\mathrm{r}}$ are the concentrations of the permeate and retentate solutions, respectively. The retentate solutions are sampled at the membrane surface.

The membrane retention coefficient $R_{\mathrm{m}}$ is obtained by extrapolation of $R_{\mathrm{obs}}$ at zero flux: ${ }^{53}$

$$
\ln \left(\frac{1-R_{\mathrm{obs}}}{R_{\mathrm{obs}}}\right)=\ln \left(\frac{1-R_{\mathrm{m}}}{R_{\mathrm{m}}}\right)+\frac{J}{k_{\mathrm{BL}}}
$$

where $J$ is the flux density $\left(\mathrm{m}^{3} \mathrm{~m}^{-2} \mathrm{~s}^{-1}\right)$ and $k_{\mathrm{BL}}$ is the mass transfer coefficient in the boundary layer $\left(\mathrm{m} \mathrm{s}^{-1}\right)$.

4.4.4. Scanning electron microscope (SEM). Membrane samples were cryofractured in liquid nitrogen and sputter coated with gold (Emitech K550X, Quorum Technologies Ltd, UK). Cross-sectional images obtained using a Phenom XL scanning electron microscope (Phenom World, The Netherlands) provide information on the structure of the prepared membranes.

\section{Results and discussion}

\subsection{Alternative solvent shortlisting}

CTA's $\delta_{\mathrm{d}}$ and $\delta_{\mathrm{p}}$ determined based on the results of solubility trials are similar to those of Cellidora A, Bayer (see Tables 6 and 7). $\delta_{\mathrm{h}}$ is however $2.4 \mathrm{MPa}^{1 / 2}$ lower than Bayer's polymer, indicating a lower hydroxyl content. The determined solubility radius $R_{0}$ of CTA is 2.5 times smaller than that of Cellidora A, possibly due to a more restrictive applied solubility criteria, i.e. complete dissolution of $12 \mathrm{wt} \%$ polymer at $25{ }^{\circ} \mathrm{C}$. Solvents among Hansen's database and from the literature ${ }^{51,54,55}$ have been shortlisted for their dissolution potential and water solubility (see Table 7). In particular, a selection criteria of RED smaller than 3.0 was applied to solvents. This arbitrary threshold was deemed necessary to keep time for experimentation within reasonable limits. It was furthermore observed that water solubility did not constitute a discriminatory factor for solvent shortlisting. In the 3D Hansen solubility space, CTA 
Table 7 HSPs and REDs of alternative solvents

\begin{tabular}{|c|c|c|c|c|c|c|}
\hline Alternative solvent & $\delta_{\mathrm{d}}(\mathrm{MPa})^{1 / 2}$ & $\delta_{\mathrm{p}}(\mathrm{MPa})^{1 / 2}$ & $\delta_{\mathrm{h}}(\mathrm{MPa})^{1 / 2}$ & $R_{0}(\mathrm{MPa})^{1 / 2}$ & RED (CTA) & RED (CDA) \\
\hline $\mathrm{CTA}^{a}$ & 18.2 & 11.4 & 8.4 & 3.0 & - & - \\
\hline $\mathrm{CDA}^{a}$ & 16.2 & 9.9 & 8.1 & 4.9 & - & - \\
\hline Dimethyl carbonate $^{b}$ & 15.5 & 8.6 & 9.7 & - & 2.1 & 0.5 \\
\hline Ethyl lactate ${ }^{b}$ & 16.0 & 7.6 & 12.5 & - & 2.4 & 1.0 \\
\hline Ethyl levulinate ${ }^{b}$ & 16.5 & 7.8 & 6.8 & - & 1.7 & 0.5 \\
\hline Gamma-valerolactone $^{b}$ & 16.9 & 11.5 & 6.3 & - & 1.1 & 0.6 \\
\hline Methyl lactate $^{b}$ & 16.9 & 8.3 & 16.1 & - & 2.9 & 1.7 \\
\hline Methyl levulinate ${ }^{b}$ & 16.7 & 8.5 & 7.5 & - & 1.4 & 0.4 \\
\hline Triethyl phosphate $b$ & 16.7 & 11.4 & 9.2 & - & 1.0 & 0.4 \\
\hline
\end{tabular}

is situated in a little dense area with few solvents, giving no RED of shortlisted solvents lower than 1.

Other parameters, found in Table 8, are based on available data. NMP being a common solvent is included in Table 8 for comparison reasons. Recent attention has been given to solvents under development such as gamma-valerolactone and methyl levulinate. This could have encouraged certain researchers to work on the characterization of the solvents and might partly explain why information on physico-chemical properties can be found. On the other hand, the scarcity of data in European Chemicals Agency's databases is indicative of a general information gap. ${ }^{56}$ For example, data on toxicity and environmental fate of these solvents remains limited and do not allow complete comparisons between solvents to be drawn.

Although no solvent has known mutagenic, carcinogenic or reprotoxic properties, 4 solvents have associated health hazard statements under the GHS. Triethyl phosphate is harmful if swallowed (H302). Ethyl lactate, methyl lactate and gammavalerolactone may cause serious eye irritation or damage (H318 and H319). The two alkyl lactates may also cause respiratory irritation (H335). It calls for appropriate engineering and administrative controls and the use of personal protective equipment to maintain worker safety. This also holds true for volatility and flammability issues. With initial boiling points lower than $250{ }^{\circ} \mathrm{C}$ at $1 \mathrm{bar}$, the 7 shortlisted solvents are all defined as volatile organic compounds according to the European Directive 2004/42/CE. Three solvents have flammability hazard statements: ethyl and methyl lactate (H226) and dimethyl carbonate (H225). Low flash points, especially that of dimethyl carbonate, make scaling-up a more cumbersome process. Explosion-proof equipment is recommended and inert gas may be used in a fully closed vessel for polymer solution preparation to reduce oxygen content. Adequate ventilation in the surrounding environment minimizes the formation of flammable atmosphere by keeping solvent vapours below the lower explosion limit. At first glance, the flammability hazard has substituted the reprotoxicity hazard of common solvents (NMP, DMA, DMF). It can also be argued that high risks linked to flammable solvents are mainly limited to heating during polymer solution preparation, whereas those of reprotoxic solvents are temperature-independent and can therefore be problematic throughout the solvents' life cycle. As for environmental criteria, the shortlisted solvents have bioconcentration factors lower than 500 and logarithms of the octanol-water partition coefficient lower than 4, indicating low levels of bioaccumulation potential. No ecotoxicity is revealed. Triethyl phosphate is the only non-readily biodegradable solvent, indicating the absence of rapid and ultimate degradation in most environments including biological sewage treatment plants. Optimized aerobic conditions are necessary to potentially biodegrade it. Given its high boiling point, recovery from liquid waste streams by distillation is expected to be energy-intensive. For alkyl lactates and alkyl levulinates, hydrolysis is a feasible degradation pathway. However, rapid conversion into their respective acids requires special use and storage to avoid contact with water.

The fabrication processes of the shortlisted solvents have been investigated (see Table 9) and hotspots pointed out. Dimethyl carbonate and triethyl phosphate are the two nonbiosourced solvents of the list. The main commercial production pathway for dimethyl carbonate is the oxidative carbonylation of methanol with typical reaction conditions equal to $120{ }^{\circ} \mathrm{C}$ and 27 bar. ${ }^{57}$ Currently, no renewably derivable feestock is used but methanol could be obtained from biomass. Low values of intensity-based metrics reflect the low number of reactions and purification steps needed. GarciaHerrero $^{57}$ estimates process mass intensity, excluding water, and energy intensity to be equal to $1.61 \mathrm{~kg}$ and $22.7 \mathrm{MJ}$ per $\mathrm{kg}$ dimethyl carbonate, respectively. Energy consumption is mainly accounted for by the use of steam in separation steps. Extensive recovery of non-reacted input material and catalysts lowers waste intensity to $0.31 \mathrm{~kg} \mathrm{~kg}^{-1}$ dimethyl carbonate. Triethyl phosphate production process from phosphorus oxychloride and ethanol takes place in milder conditions (10-30 ${ }^{\circ} \mathrm{C}, 0.08-0.15$ bar). ${ }^{58}$ Nonetheless, the key issue is the use of phosphate rock as feedstock. It is converted to white phosphorus, which is then used to make triethyl phosphate through intermediates phosphorus trichloride and phosphorus oxychloride. Phosphate rock is identified as a critical raw material by the European Union: production is limited to three main countries, substitution is impossible and no current recycling is done. ${ }^{47}$ Some researchers suggest that affordable phosphorus reserves may be depleted in 50-100 
Table 8 Metrics for the solvent applied to 7 shortlisted alternative solvents and NMP

\begin{tabular}{|c|c|c|c|c|c|c|}
\hline Parameter & Metric & $\mathrm{NMP}^{56,70}$ & $\begin{array}{l}\text { Dimethyl } \\
\text { carbonate }^{56,71}\end{array}$ & Ethyl lactate ${ }^{56,72}$ & $\begin{array}{l}\text { Ethyl } \\
\text { levulinate } \\
56,73-75\end{array}$ & $\begin{array}{l}\text { Gamma- } \\
\text { valerolactone } e^{56,73,76-78}\end{array}$ \\
\hline \multirow[t]{2}{*}{ Solvency } & Relative energy difference with $\mathrm{CTA}^{a}$ & 0.5 & 2.1 & 2.4 & 1.7 & 1.1 \\
\hline & Solubility in water & $\begin{array}{l}\text { Miscible; } 1 \mathrm{~kg} \mathrm{~L}^{-1} \text { at } \\
20^{\circ} \mathrm{C}\end{array}$ & $\begin{array}{l}114.7-138.2 \mathrm{~g} \mathrm{~L}^{-1} \text { at } \\
20-25^{\circ} \mathrm{C} \text { and } \mathrm{pH} 6\end{array}$ & Miscible & $12.6 \mathrm{~g} \mathrm{~L}^{-1}$ & Miscible \\
\hline \multirow[t]{2}{*}{ Stability } & Thermal decomposition & No data & No data & No data & No data & $\begin{array}{l}>600^{\circ} \mathrm{C} \text {, appropriate } \\
\text { catalyst necessary }\end{array}$ \\
\hline & Hydrolysis & No data & $\begin{array}{l}\text { Half-life } 5 \text { days at } \\
50^{\circ} \mathrm{C}\end{array}$ & $\begin{array}{l}\text { Half-life } 72 \text { days at } \\
\text { pH } 7 \text { and } 7 \text { days at } \\
\text { pH } 8\end{array}$ & $\begin{array}{l}6.0 \% \text { after } 5 \text { days } \\
\text { at } 40{ }^{\circ} \mathrm{C}\end{array}$ & $>28$ days at $60^{\circ} \mathrm{C}$ \\
\hline \multirow[t]{2}{*}{ Volatility } & Vapour pressure & $0.039 \mathrm{kPa}$ at $20^{\circ} \mathrm{C}$ & $\begin{array}{l}5.3-7.6 \mathrm{kPa} \text { at } \\
20-25^{\circ} \mathrm{C}\end{array}$ & $\begin{array}{l}0.51-0.87 \mathrm{kPa} \text { at } \\
20-25^{\circ} \mathrm{C}\end{array}$ & $0.011 \mathrm{kPa}$ at $25^{\circ} \mathrm{C}$ & $0.65 \mathrm{kPa}$ at $25^{\circ} \mathrm{C}$ \\
\hline & Boiling point & $202-204{ }^{\circ} \mathrm{C}$ & $89.7-91^{\circ} \mathrm{C}$ & $154^{\circ} \mathrm{C}$ & $206^{\circ} \mathrm{C}$ & $207^{\circ} \mathrm{C}$ \\
\hline \multirow[t]{2}{*}{ Inflammability } & Flash point & $91^{\circ} \mathrm{C}$ & $14-19^{\circ} \mathrm{C}$ & $46-54^{\circ} \mathrm{C}$ & $90^{\circ} \mathrm{C}$ & $81^{\circ} \mathrm{C}$ \\
\hline & & & $\begin{array}{l}\text { H225 (highly } \\
\text { flammable liquid } \\
\text { and vapour) }\end{array}$ & $\begin{array}{l}\text { H226 (flammable } \\
\text { liquid and vapour) }\end{array}$ & & \\
\hline $\begin{array}{l}\text { Other physical } \\
\text { hazard }\end{array}$ & $\begin{array}{l}\text { Explosiveness, self-reactivity, } \\
\text { pyrophoricity, oxidizing, corrosivity }\end{array}$ & None & None & None & None & No data \\
\hline Acute toxicity & Acute toxicity estimate values & None & None & None & None & None \\
\hline $\begin{array}{l}\text { Specific target organ } \\
\text { toxicity }\end{array}$ & Single and repeated exposure tests & None & None & None & None & No data \\
\hline $\begin{array}{l}\text { Aspiration hazard or } \\
\text { irritation }\end{array}$ & $\begin{array}{l}\text { Aspiration hazard, skin corrosion or } \\
\text { irritation, serious eye damage or eye } \\
\text { irritation, respiratory or skin sensitization }\end{array}$ & $\begin{array}{l}\text { H315 (causes skin } \\
\text { irritation) } \\
\text { H319 (causes } \\
\text { serious eye } \\
\text { irritation) } \\
\text { H335 (may cause } \\
\text { respiratory } \\
\text { irritation) }\end{array}$ & None & $\begin{array}{l}\text { H335 (may cause } \\
\text { respiratory irritation) } \\
\text { H318 (causes serious } \\
\text { eye damage) }\end{array}$ & None & $\begin{array}{l}\text { H319 (causes serious eye } \\
\text { irration) }\end{array}$ \\
\hline $\begin{array}{l}\text { Carcinogenic, } \\
\text { mutagenic, reprotoxic }\end{array}$ & $\begin{array}{l}\text { Germ cell mutagenicity tests } \\
\text { Carcinogenicity tests } \\
\text { Reprotoxicity tests }\end{array}$ & $\begin{array}{l}\text { H360D (may } \\
\text { damage the unborn } \\
\text { child) }\end{array}$ & None & None & None & No data \\
\hline Biodegradability & Ready biodegradability & $\begin{array}{l}\text { Readily } \\
\text { biodegradable }\end{array}$ & $\begin{array}{l}\text { Readily } \\
\text { biodegradable }\end{array}$ & $\begin{array}{l}\text { Readily } \\
\text { biodegradable }\end{array}$ & No data & No data \\
\hline \multirow[t]{2}{*}{ Bioaccumulation } & Bioconcentration factor & Estimated 3 & $\begin{array}{l}0.23-0.354 \text { at } \\
20-25^{\circ} \mathrm{C} \text { pH } 6.5-7.4\end{array}$ & 3 & Estimated 1.26 & -0.272 \\
\hline & $\begin{array}{l}\text { Logarithm octanol-water partition } \\
\text { coefficient }\end{array}$ & -0.46 at $25^{\circ} \mathrm{C}$ & Estimated 3.2 & 0.31 & 0.38 & Estimated 1.00 \\
\hline Ecotoxicity & $\begin{array}{l}\text { Acute aquatic toxicity } \\
\text { Chronic aquatic toxicity }\end{array}$ & None & None & None & None & No data \\
\hline Parameter & Metric & & Methyl lactate ${ }^{56,79,80}$ & & $\begin{array}{l}\text { Methyl } \\
\text { levulinate }^{73-75}\end{array}$ & Triethylphosphate ${ }^{56,81}$ \\
\hline \multirow[t]{2}{*}{ Solvency } & Relative energy difference with CTA ${ }^{a}$ & & 2.9 & & 1.4 & 1.0 \\
\hline & Solubility in water & & Miscible & & Miscible & $500 \mathrm{~g} \mathrm{~L}^{-1}$ at $25^{\circ} \mathrm{C}$ \\
\hline \multirow[t]{2}{*}{ Stability } & Thermal decomposition & & No data & & No data & No data \\
\hline & Hydrolysis & & $\begin{array}{l}\text { Half-lives estimated } 6 \\
\mathrm{pH} \text { values of } 7,8 \text { and }\end{array}$ & $\begin{array}{l}3,6.8 \text { and } 0.68 \text { days at } \\
9, \text { respectively }\end{array}$ & $\begin{array}{l}7.9 \% \text { after } 5 \text { days at } \\
40{ }^{\circ} \mathrm{C}\end{array}$ & Half-life 5.5 years \\
\hline \multirow[t]{2}{*}{ Volatility } & Vapour pressure & & $0.340 \mathrm{kPa}$ at $20^{\circ} \mathrm{C}$ & & $0.446 \mathrm{kPa}$ at $60^{\circ} \mathrm{C}$ & $0.0523 \mathrm{kPa}$ at $25^{\circ} \mathrm{C}$ \\
\hline & Boiling point & & $144^{\circ} \mathrm{C}$ & & $193-195{ }^{\circ} \mathrm{C}$ & $215.5^{\circ} \mathrm{C}$ \\
\hline
\end{tabular}


Table 8 (Contd.)

\begin{tabular}{|c|c|c|c|c|}
\hline Parameter & Metric & Methyl lactate ${ }^{56,79,80}$ & $\begin{array}{l}\text { Methyl } \\
\text { levulinate }\end{array}$ & Triethylphosphate $^{56,81}$ \\
\hline Inflammability & Flash point & $\begin{array}{l}58^{\circ} \mathrm{C} \\
\mathrm{H} 226 \text { (flammable liquid and vapour) }\end{array}$ & $72^{\circ} \mathrm{C}$ & $115^{\circ} \mathrm{C}$ \\
\hline Other physical hazard & $\begin{array}{l}\text { Explosiveness, self-reactivity, pyrophoricity, oxidizing, } \\
\text { corrosivity }\end{array}$ & None & No data & None \\
\hline Acute toxicity & Acute toxicity estimate values & None & No data & $\begin{array}{l}\text { H302 (harmful if } \\
\text { swallowed) }\end{array}$ \\
\hline $\begin{array}{l}\text { Specific target organ } \\
\text { toxicity }\end{array}$ & Single and repeated exposure tests & None & No data & None \\
\hline $\begin{array}{l}\text { Aspiration hazard or } \\
\text { irritation }\end{array}$ & $\begin{array}{l}\text { Aspiration hazard, skin corrosion or irritation, serious eye } \\
\text { damage or eye irritation, respiratory or skin sensitization }\end{array}$ & $\begin{array}{l}\text { H335 (may cause respiratory irritation) } \\
\text { H319 (serious eye irritation) }\end{array}$ & No data & None \\
\hline $\begin{array}{l}\text { Carcinogenic, mutagenic, } \\
\text { reprotoxic }\end{array}$ & $\begin{array}{l}\text { Germ cell mutagenicity tests } \\
\text { Carcinogenicity tests } \\
\text { Reprotoxicity tests }\end{array}$ & None & No data & None \\
\hline Biodegradability & Ready biodegradability & Readily biodegradable & No data & $\begin{array}{l}\text { Inherently } \\
\text { biodegradable }\end{array}$ \\
\hline Bioaccumulation & $\begin{array}{l}\text { Bioconcentration factor } \\
\text { Logarithm octanol-water partition coefficient }\end{array}$ & $\begin{array}{l}-0.2 \\
\text { Estimated }-0.67\end{array}$ & $\begin{array}{l}\text { Estimated } 1.00 \\
-0.17\end{array}$ & $\begin{array}{l}<1.3 \\
1.11\end{array}$ \\
\hline Ecotoxicity & $\begin{array}{l}\text { Acute aquatic toxicity } \\
\text { Chronic aquatic toxicity }\end{array}$ & None & No data & None \\
\hline
\end{tabular}

${ }^{a}$ Source HSPiP software database. ${ }^{51}$

Table 9 Metrics for the solvent fabrication processes of the 7 shortlisted alternative solvents

\begin{tabular}{|c|c|c|c|c|c|c|c|c|}
\hline Metric & Simplified metric & $\begin{array}{l}\text { Dimethyl } \\
\text { carbonate }^{57}\end{array}$ & Ethyl lactate ${ }^{60,62}$ & $\begin{array}{l}\text { Ethyl } \\
\text { levulinate }\end{array}$ & $\begin{array}{l}\text { Gamma- } \\
\text { valerolactone } \\
64,67,68,70\end{array}$ & Methyl lactate ${ }^{61,62}$ & $\begin{array}{l}\text { Methyl } \\
\text { levulinate }^{64}\end{array}$ & $\begin{array}{l}\text { Triethyl } \\
\text { phosphate }\end{array}$ \\
\hline $\begin{array}{l}\text { Renewable } \\
\text { intensity }\end{array}$ & $\begin{array}{l}\text { Number of } \\
\text { renewably } \\
\text { derivable } \\
\text { feedstocks }\end{array}$ & 0 & 1 (lactic acid) & $\begin{array}{l}1 \text { (levulinic } \\
\text { acid) }\end{array}$ & $\begin{array}{l}1 \text { (either levulinic acid or } \\
\text { ethyl levulinate) }\end{array}$ & 1 (lactic acid) & $\begin{array}{l}1 \text { (levulinic } \\
\text { acid) }\end{array}$ & 0 \\
\hline $\begin{array}{l}\text { Process mass } \\
\text { intensity }\end{array}$ & $\begin{array}{l}\text { Number of } \\
\text { reactions and } \\
\text { separation steps }\end{array}$ & $\begin{array}{l}1.61 \mathrm{~kg} \mathrm{~kg}^{-1}, 4 \\
\text { reactions }\end{array}$ & $\begin{array}{l}5 \text { reactions, calcium } \\
\text { sulphate separation } \\
\left(1 \mathrm{~kg} \mathrm{~kg}^{-1} \text { of lactic acid }\right)\end{array}$ & 5 reactions & Min. 3 reactions & $\begin{array}{l}5 \text { reactions, calcium } \\
\text { sulphate separation } \\
\left(1 \mathrm{~kg} \mathrm{~kg}^{-1} \text { of lactic acid }\right)\end{array}$ & 5 reactions & Min. 4 reactions \\
\hline $\begin{array}{l}\text { Energy } \\
\text { intensity }\end{array}$ & $\begin{array}{l}\text { Operational } \\
\text { conditions }\end{array}$ & $\begin{array}{l}22.7 \mathrm{MJ} \mathrm{kg}^{-1} \\
120^{\circ} \mathrm{C}, 27 \mathrm{bar}\end{array}$ & $50-100^{\circ} \mathrm{C}, 1$ bar & $\begin{array}{l}100-230^{\circ} \mathrm{C}, 1 \\
\text { bar }\end{array}$ & $140-380^{\circ} \mathrm{C}, 30-55$ bar & $50-100^{\circ} \mathrm{C}, 1 \mathrm{bar}$ & $\begin{array}{l}100-230{ }^{\circ} \mathrm{C}, 1 \\
\text { bar }\end{array}$ & $\begin{array}{l}10-30{ }^{\circ} \mathrm{C} \\
0.08-0.15 \text { bar }\end{array}$ \\
\hline $\begin{array}{l}\text { Use of critical } \\
\text { elements }\end{array}$ & - & None & None & None & None & None & None & Phosphate rock \\
\hline
\end{tabular}


years. ${ }^{59}$ In response to the use of finite resources and their potential depletion, interest at the international level has been given to renewable resources. Carbohydrates from sugar-based biomass and lignocellulose biomass can be converted to building blocks and platform chemicals such as lactic acid and levulinic acid for further chemical synthesis. Ethyl lactate and methyl lactate can both be recovered by distillation after catalyzed esterification of lactic acid with ethanol and methanol, respectively. ${ }^{60,61}$ Reaction conditions are mild $\left(50-100{ }^{\circ} \mathrm{C}, 1\right.$ bar) but equilibrium limitations specific to esterifications need to be overcome. ${ }^{60}$ Constable et al. ${ }^{37}$ consider that esterification reactions have average reaction mass efficiencies of $67 \%$ and mass intensities of $11.4 \mathrm{~kg} \mathrm{~kg}^{-1}$ ester. The reaction mass efficiency is defined as the percentage of the mass of the reactants that remain in the product. ${ }^{37}$ The total number of chemical steps in the synthesis of both lactate esters are predominantly due to lactic acid synthesis. In the conventional process, lactic acid recovery and purification from fermentation broths require complex separation steps. ${ }^{62}$ One separation step involves calcium sulphate, of which one kilogram needs to be disposed of for every kilogram of lactic acid produced. ${ }^{62}$ Advances in electrodialysis technolgies seek to eliminate this salt waste. ${ }^{63}$ The production of ethyl and methyl levulinate also involves a final esterification step. Several reaction pathways are being investigated, among which synthesis from levulinic acid and furfuryl alcohol. ${ }^{64}$ Levulinic acid can be obtained by acid-catalyzed hydrolysis of carbohydrates at $100-250{ }^{\circ} \mathrm{C}$ with a relatively high yield. ${ }^{65,66}$ Isolating and purifying it is however more complicated. ${ }^{65}$ Gamma-valerolactone can be obtained by hydrogenation from either levulinic acid or ethyl levulinate with high temperatures and pressures of $\mathrm{H}_{2}$ and a metal catalyst. ${ }^{64,67,68}$ On average, hydrogenation reactions have reaction mass efficiencies of $74 \%$ and mass intensities of $18.6 \mathrm{~kg} \mathrm{~kg}^{-1} \cdot{ }^{61} \mathrm{Jessop}^{15}$ considers gamma-valerolactone can be obtained by only 4 steps. Interestingly, Zhang ${ }^{69}$ reports on recent advances made in obtaining gamma-valerolactone from a one-pot-conversion of carbohydrates such as fructose with 3 main reactions. The most striking conclusion to emerge from the analysis of the solvents' fabrication processes is that data on intensity-based metrics is lacking, making it tedious to compare them in a comprehensive manner.

\subsection{Solubility trials with shortlisted solvents}

None of the 7 shortlisted alternative solvents was found to have a solvency power high enough to totally dissolve CTA. Triethyl phosphate only partially dissolved CTA. Blends of alternative solvents were tested and gave similar negative results. These results agree with the REDs greater or equal to 1 (see Table 7). In the literature, difficulties have also been encountered to find suitable alternative solvents for CTA. It has for example been found that a lower polymer concentration (i.e. $10 \mathrm{wt} \%$ ) was necessary for gamma-valerolactone to dissolve CTA. ${ }^{83}$ Overall, our solubility trials pinpoint a scientific barrier linked to the limited number of alternative solvents with appropriate solvency power. Ongoing research in green chemistry offers promising insights into new solvents, in par- ticular those produced from biobased platform chemicals. An example is dihydrolevoglucosenone (Cyrene), a molecule derived from cellulose in a two-step process and currently under development. ${ }^{82}$ Its HSPs make it a promising alternative for dipolar aprotic solvents and a potential solvent for CTA in the near future (RED equal to 0.7).

CDA was tested as an alternative polymer to CTA. Its lower degree of substitution makes it easier to solubilize by common solvents. ${ }^{84}$ REDs of the shortlisted alternative solvents are lower for CDA than for CTA and are lower or equal to 1.0, with the exception of methyl lactate (see Table 7). All 7 solvents, including methyl lactate, totally dissolved CDA in the solubility trials. Limitations in the conventional hypothesis in determining RED values may explain why the value for methyl lactate - CDA is greater than 1.0 whereas CDA is found to be soluble in methyl lactate. The hypothesis is that a sphere describes the solubility volume of a given polymer. Limitations have been observed in the literature $^{85}$ and certain authors suggest that an ellipsoid may better fit data than a sphere. ${ }^{86}$ Wiśniewski et al. ${ }^{87}$ further acknowledge that solubility volumes are generally unsymmetrical.

In additional solubility trials, only ethyl and methyl lactate dissolved LiCl. Further testing was thus carried out with the two alkyl lactates. Although out of the scope of this work, this selection by no means disqualifies the other 5 solvents for membrane preparation, especially if a different additive were to be used.

Homogeneous ternary mixtures (CDA: LiCl: solvent) with weight compositions equal to $12: 1: 87$ and $15: 3: 82$ were obtained for both alkyl lactates. Furthermore, the viscosity range (1.2-4.9 Pa s) allowed to cast flat sheet membranes and is also appropriate for hollow fibre casting. As for the stability of the polymer solution, no gel formation nor crystallization has been visually observed. Quantitative characterization could be particularly relevant during the scaling-up process from flat sheet membrane to hollow fibre preparation.

\subsection{Membrane performance and characterization}

Permeabilities of flat sheet membranes prepared in different coagulation baths are detailed in Table 10. The addition of glycerol or the solvent to the aqueous coagulation bath is expected to lower the membrane formation rate and decrease the formation of finger cavities so as to avoid having membranes with lower rejection to micro-solutes as compared to membranes prepared with water as sole non-solvent. ${ }^{9}$ Results show that membranes prepared with ethyl lactate have very

Table 10 Permeability values $\left(\mathrm{L} \mathrm{h}^{-1} \mathrm{~m}^{-2} \mathrm{bar}^{-1}\right)$ of CDA flat sheet membranes prepared with $82 \mathrm{wt} \%$ ethyl lactate or methyl lactate and $3 \mathrm{wt} \%$ $\mathrm{LiCl}$ at $80^{\circ} \mathrm{C}$

\begin{tabular}{lcl}
\hline & \multicolumn{2}{c}{ Coagulation bath composition } \\
\cline { 2 - 3 } $\begin{array}{l}\text { Alternative } \\
\text { solvent }\end{array}$ & $\begin{array}{l}15 \mathrm{v} / \mathrm{v} \% \text { solvent } \\
\text { in water }\end{array}$ & $\begin{array}{l}15 \mathrm{v} / \mathrm{v} \% \text { glycerol } \\
\text { in water }\end{array}$ \\
\hline Ethyl lactate & 0 & 15 \\
Methyl lactate & 202 & 92
\end{tabular}


Table 11 Permeability and retention values of CDA flat sheet membranes prepared with $82 \mathrm{wt} \%$ methyl lactate and $3 \mathrm{wt} \% \mathrm{LiCl}$ at different casting temperatures and coagulated in a $15 \mathrm{v} / \mathrm{v} \%$ methyl lactate bath

\begin{tabular}{lll}
\hline $\begin{array}{l}\text { Casting } \\
\text { temperature }\left({ }^{\circ} \mathrm{C}\right)\end{array}$ & $\begin{array}{l}\text { Permeability } \\
\left(\mathrm{L} \mathrm{h}^{-1} \mathrm{~m}^{-2} \mathrm{bar}^{-1}\right)\end{array}$ & $\begin{array}{l}\text { PEG } \\
\text { retention }(\%)\end{array}$ \\
\hline 60 & 49 & 94 \\
70 & 357 & 93 \\
80 & 188 & 91
\end{tabular}

low pure water permeabilities (0 and $15 \mathrm{~L} \mathrm{~h}^{-1} \mathrm{~m}^{-2} \mathrm{bar}^{-1}$ ), which are irrelevant for ultrafiltration applications. Further screening trials at different casting temperatures have thus been carried out on the most permeable membrane, i.e. methyl lactate as solvent in both the polymer solution and coagulation bath. Values in Table 11 show that casting temperature, which directly impacts on energy intensity, has a significant effect on permeability and less so for PEG retention. Permeability values of membranes prepared with methyl lactate are comparable to those found in the literature for ultrafiltration membranes. ${ }^{88}$ Retention rates of $200 \mathrm{kDa}$ PEG above $90 \%$ suggest membrane pore diameters below $48 \mathrm{~nm}$. Indeed, the calculated hydrodynamic radius of the tracer as described by Meireles et al. ${ }^{89}$ equals $24 \mathrm{~nm}$. The sponge substructure containing finger-like pores near the skin layer as shown in Fig. 1 is furthermore consistent with the description

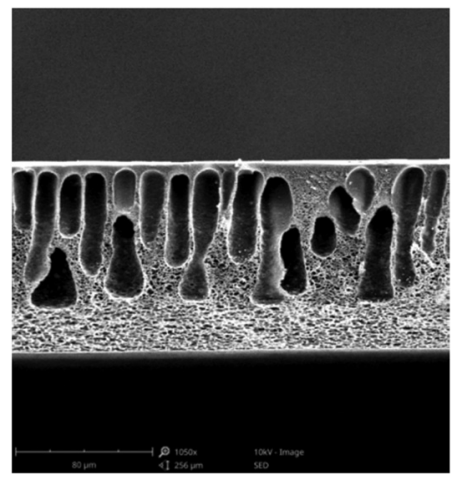

Fig. 1 Cross-sectional morphology of CDA flat sheet membrane prepared at $80^{\circ} \mathrm{C}$. by Strathmann et $a l .{ }^{90}$ of low pressure ultrafiltration membranes. Flat sheet membrane preparation in this work shows promising technical results. Although out of the scope of this work, hollow fibre preparation can be considered in a further step with complete characterization (selectivity, mechanical and chemical resistance) as indicated in Table 5.

\subsection{Metrics applied to the membrane fabrication process using methyl lactate}

The metrics in Table 12 give a brief overview of improvements and remaining challenges in using methyl lactate as alternative solvent during membrane fabrication. As reference (see Table 12), hollow fibres prepared with CTA 20 wt $\%$, LiCl 2 wt $\%$ and NMP as solvent are taken. Spinning of the reference membrane takes place at $80{ }^{\circ} \mathrm{C}$ and the bore liquid is a glycerolwater blend. The bore liquid in inner skin hollow fibre preparation can be assimilated to the coagulation bath in flat sheet membrane preparation, as carried out in this work. Industrial compositions and process conditions remain confidential but are not expected to significantly differ from the ones mentionned above. Compared to the reference, three improvements in the membrane preparation process with methyl lactate exist:

(i) increased number of renewably derivable feedstocks: the renewably intensity increases from 1.0 to $4.9 \mathrm{~kg} \mathrm{~kg}^{-1}$ since NMP is petrochemical-based, whereas methyl lactate can be obtained by fermentation of carbohydrates,

(ii) reduced number of solvents: methyl lactate is used both in the polymer solution and coagulation bath, instead of having two distinct solvents,

(iii) reduced number of compounds per liquid stream: coagulation and rinsing waste streams each contain 3 (water, methyl lactate and $\mathrm{LiCl}$ ) instead of 4 compounds (water, NMP, glycerol and $\mathrm{LiCl}$ ), which simplifies waste management.

Challenges remain to improve environmental and technical performances. Current process mass intensity of membranes prepared with CDA 15 wt\% equals $6.7 \mathrm{~kg} \mathrm{~kg}^{-1}$, whereas that of industrial membranes taken as reference equals $5.0 \mathrm{~kg} \mathrm{~kg}^{-1}$. Increasing the polymer's weight percentage in the polymer solution will reduce mass intensity but also lead to less permeable sponge-structured membranes. The skin layer where the polymer first coagulates is expected to have an increased strength linked to higher polymer concentration and a lower ten-

Table 12 Metrics applied to the membrane fabrication process of CDA flat sheet membranes

\begin{tabular}{|c|c|c|c|}
\hline Metric & Simplified metric & Reference membrane $^{a}$ & CDA flat sheet membrane \\
\hline \multirow[t]{2}{*}{ Renewable intensity } & & $1.0 \mathrm{~kg} \mathrm{~kg}^{-1}$ & $4.9 \mathrm{~kg} \mathrm{~kg}^{-1}$ \\
\hline & Number of renewably derivable feedstocks & 1 (CTA $)^{\circ}$ & 2 (CDA, methyl lactate) \\
\hline \multirow[t]{3}{*}{ Process mass intensity } & & $5.0 \mathrm{~kg} \mathrm{~kg}^{-1}$ & $6.7 \mathrm{~kg} \mathrm{~kg}^{-1}$ \\
\hline & Number of reactions and separation steps & 1 phase separation step & 1 phase separation step \\
\hline & Number of solvents & 3 (NMP, water, glycerol) & 2 (methyl lactate, water) \\
\hline \multirow[t]{3}{*}{ Energy intensity } & Operational conditions & $80^{\circ} \mathrm{C}, 1 \mathrm{bar}$ & $60-80^{\circ} \mathrm{C}, 1 \mathrm{bar}$ \\
\hline & Number of liquid streams to treat & 2 (coagulation, rinsing) & 2 (coagulation, rinsing) \\
\hline & Number of solvents per liquid stream & 4 (water, NMP, glycerol, LiCl) & 3 (water, methyl lactate, $\mathrm{LiCl}$ ) \\
\hline Use of critical elements & - & None & None \\
\hline
\end{tabular}

${ }^{a}$ Polymer solution composition: CTA $20 \mathrm{wt} \%$, LiCl $2 \mathrm{wt} \%$ and NMP as solvent. Spining temperature: $80{ }^{\circ} \mathrm{C}$. Bore liquid: glycerol-water blend. 
dency to rupture and initiate fingers. ${ }^{90}$ Energy and solvent intensity can also be further optimized by fine tuning casting temperature and coagulation bath composition, respectively. One might question to what extent intensity-based metrics can be optimized. The ideal NIPS process consists of a bio-sourced polymer as unique input: process mass intensity equal to $1 \mathrm{~kg} \mathrm{~kg}^{-1}$ and energy intensity equal to $0 \mathrm{MJ} \mathrm{kg}^{-1}$. This entails no heating, no solvent and, by extension, no phase inversion. In reality, the polymer weight percentage encountered in the literature is rarely above $35 \mathrm{wt} \%$ due to viscosity increase of the polymer solution. ${ }^{91}$ The lowest process mass intensity obtained would be $2.9 \mathrm{~kg} \mathrm{~kg}^{-1}$. If all inputs were derived from renewable feedstocks, renewable intensity would also equal $2.9 \mathrm{~kg} \mathrm{~kg}^{-1}$. No indication is however provided about the technical feasilibity of obtaining performant membranes with such values. Trade-offs between use of resources and membrane properties are inevitable.

\section{Concluding remarks}

Measuring sustainability performance is a prerequisite for improving it and supports researchers in their endeavour to develop greener membranes and associated processes. The metric-based approach as developed in this study is a first step to rationalize sustainable membrane preparation. Hotspots and hazards other than solvent reprotoxicity have been pointed out and technical feasibility assessed.

Ultrafiltration CDA membranes have been prepared with methyl lactate, a non-toxic but flammable solvent. Although other solvents labelled as green by the scientific community have been studied, the field of chemistry has yet to propose a vast choice of alternative solvents with high solvency power for membrane applications. Extensive information on the environmental fate and toxicity of these newly commercialized solvents could help make better-informed decisions.

As for membrane science, accurate tools for predicting the impact of process parameters on membrane properties could simplify the integration of EHS criteria.

Discriminating solvents early in the screening stage remains inconclusive. For complete comparison, technical feasibility is to be considered alongside LCA, socio-economic and risk analysis. The three analysis require to anticipate scale-up by providing information specific to the design and production site in addition to data collected during our metric-based approach. In other words, the underlying vision advocated is to embed ecodesign practices into membrane science.

\section{Conflicts of interest}

There are no conflicts to declare.

\section{Acknowledgements}

The research reported in this publication was financially supported by the Université Fédérale de Toulouse (PRES) and
Région Occitanie/Pyrénées-Méditerranée, France. The authors gratefully thank ABC Membranes and Aquasource (SUEZ) for the technical advice. Special thanks to Philippe Aptel for his useful suggestions.

\section{References}

1 A. Basile and C. Charcosset, Integrated membrane systems and processes, John Wiley \& Sons, Ltd., Newark, California, 2015.

2 J. C. Charpentier, Ind. Eng. Chem. Res., 2007, 46, 3465-3485.

3 Membrane technology and applications, ed. R. W. Baker, John Wiley \& Sons, Ltd., Newark, California, 2012.

4 A. Bottino, G. Capannelli, S. Munari and A. Turturro, Desalination, 1988, 68, 167-177.

5 A. K. Hołda and I. F. Vankelecom, J. Membr. Sci., 2017, 450, 499-511.

6 I. Cabasso, E. Klein and J. K. Smith, J. Appl. Polym. Sci., 1976, 20, 2377-2394.

7 A. Figoli and A. Criscuoli, Sustainable Membrane Technology for Water and Wastewater Treatment, Springer, Berlin, 2017.

8 D. M. Koenhen, M. H. V. Mulder and C. A. Smolders, J. Appl. Polym. Sci., 1977, 21, 199-215.

9 H. Strathmann, K. Kock, P. Amar and R. W. Baker, Desalination, 1975, 16, 179-203.

10 World Commission on Environment and Development, Our Common Future, Oxford University Press, Oxford, 1987.

11 European Chemicals Agency, Information on chemicals, https://echa.europa.eu/information-on-chemicals.

12 M. Razali, J. F. Kim, M. Attfield, P. M. Budd, E. Drioli, Y. M. Lee and G. Szekely, Green Chem., 2015, 17, 51965205.

13 A. Figoli, T. Marino, S. Simone, E. Di Nicolò, X. M. Li, T. He, S. Tornaghi and E. Drioli, Green Chem., 2014, 16, 4034-4059.

14 A. Hanafia, C. Faur, A. Deratani, P. Guenoun, H. Garate, D. Quemener, C. Pochat-Bohatier and D. Bouyer, J. Membr. Sci., 2017, 526, 212-220.

15 P. G. Jessop, Green Chem., 2011, 13, 1391-1398.

16 K. L. Wilson, J. Murray, H. F. Sneddon, K. M. Wheelhouse and A. J. Watson, Chem., 2017, 3, 365-368.

17 D. Prat, A. Wells, J. Hayler, H. F. Sneddon, C. R. McElroy, S. Abou-Shehada and P. J. Dunn, Green Chem., 2015, 18, 288-296.

18 K. Alfonsi, J. Colberg, P. J. Dunn, T. Fevig, S. Jennings, T. A. Johnson, H. P. Kleine, C. Knight, M. A. Nagy and D. A. Perry, Green Chem., 2008, 10, 31-36.

19 A. D. Curzons, D. C. Constable and V. L. Cunningham, Clean Technol. Environ. Policy, 1999, 1, 82-90.

20 C. Jiménez-González, A. D. Curzons, D. J. C. Constable and V. L. Cunningham, Clean Technol. Environ. Policy, 2005, 7, 42-50.

21 R. K. Henderson, C. Jiménez-González, D. J. C. Constable, S. R. Alston, G. G. Inglis, G. Fisher, J. Sherwood, S. P. Binks and A. D. Curzons, Green Chem., 2011, 13, 854-862. 
22 C. M. Alder, J. D. Hayler, R. K. Henderson, A. M. Redman, L. Shukla, L. E. Shuster and H. F. Sneddon, Green Chem., 2016, 18, 3879.

23 D. Prat, O. Pardigon, H. W. Flemming, S. Letestu, V. Ducandas, P. Isnard, E. Guntrum, T. Senac, S. Ruisseau, P. Cruciani and P. Hosek, Org. Process Res. Dev., 2013, 17, 1517-1525.

24 Y. Gu and F. Jérôme, Chem. Soc. Rev., 2013, 42, 9550-9570.

25 M. Tobiszewski, S. Tsakovski, V. Simeonov, J. Namieśnik and F. Pena-Pereira, Green Chem., 2015, 17, 4773-4785.

26 E. T. H. Vink, K. R. Rábago, D. A. Glassner and P. R. Gruber, Polym. Degrad. Stab., 2013, 80, 403-419.

27 A. Dolbry, U.S. Pat., 2059934, 1936.

28 S. Loeb and S. Sourirajan, U.S. Pat., 3133132, 1964.

29 M. Ulbricht, Polymer, 2006, 47, 2217-2262.

30 J. L. Halary, C. Noël and L. Monnerie, Desalination, 1978, 27, 197-213.

31 E. Klein, F. F. Holland, A. Donnaud, A. Lebeouf and K. Eberle, J. Membr. Sci., 1977, 2, 349-364.

32 J. Scott, Hollow Fibers: Manufacture and Applications, Noyes Data Corporation, Park Ridge, New Jersey, 1981.

33 J. M. Laîné, D. Vial and P. Moulart, Desalination, 2000, 131, 17-25.

34 H. Krässig, J. Schurz, R. G. Steadman, K. Schliefer, W. Albrecht, M. Mohring and H. Schlosser, in Ullmann's Encyclopedia of Industrial Chemistry, Wiley-VCH Verlag GmbH \& Co. KGaA, Weinheim, 2011.

35 B. M. Krishna Manda, E. Worrell and M. K. Patel, J. Cleaner Prod., 2014, 72, 153-166.

36 P. T. Anastas and J. C. Warner, Green Chemistry: Theory and Practice, Oxford University Press, Oxford, 1998.

37 D. J. Constable, A. D. Curzons and V. L. Cunningham, Green Chem., 2002, 4, 521-527.

38 A. D. Curzons, D. J. Constable, D. N. Mortimer and V. L. Cunningham, Green Chem., 2001, 3, 1-6.

39 R. A. Sheldon, ACS Sustainable Chem. Eng., 2017, 6, 32-48.

40 C. R. McElroy, A. Constantinou, L. C. Jones, L. Summerton and J. H. Clark, Green Chem., 2015, 17, 3111-3121.

41 J. F. Kim, J. T. Jung, H. Wang, E. Drioli and Y. M. Lee, in Comprehensive Membrane Science and Engineering, Elsevier Science, Oxford, 2nd edn, 2017.

42 C. M. Hansen, Doctoral dissertation, Danish Technical Press, 1967.

43 Y. Medina-Gonzalez, P. Aimar, J. F. Lahitte and J. C. Remigy, Int. J. Sustain. Eng., 2011, 4, 75-83.

44 United Nations Economic Commission for Europe, Globally harmonized system of classification and labelling of chemicals (GHS), https:/www.unece.org/fileadmin/DAM/trans/ danger/publi/ghs/ghs_rev04/English/ST-SG-AC10-30-Rev4e.

45 R. K. Henderson, C. Jiménez-González, D. J. C. Constable, S. R. Alston, G. G. A. Inglis, G. Fisher, J. Sherwood, S. P. Binks and A. D. Curzons, Green Chem., 2011, 13, 854-862.

46 M. D. Tabone, J. J. Cregg, E. J. Beckman and A. E. Landis, Environ. Sci. Technol., 2010, 44, 8264-8269.

47 European Commission, Communication from the European Parliament, the Council, the European Economic and Social Committee and the Committee of the Regions on the 2017 list of critical raw materials for the EU, https:// ec.europa.eu/transparency/regdoc/rep/1/2017/EN/COM-2017490-F1-EN-MAIN-PART-1.PDF.

48 C. Regula, E. Carretier, Y. Wyart, G. Gésan-Guiziou, A. Vincent, D. Boudot and P. Moulin, Water Res., 2014, 56, 325-365.

49 E. Zondervan and B. Roffel, J. Membr. Sci., 2008, 322, 46-51.

50 Hansen Solubility Parameters: A User's Handbook, ed. C. M. Hansen, CRC Press, Boca Raton, Florida, 2007.

51 Software HSPiP 5.0. Available at https:/www.hansen-solubility.com/downloads.php.

52 C. Li, C. Cabassud and C. Guigui, J. Membr. Sci., 2015, 475, 122-130.

53 C. Causserand, S. Rouaix, A. Akbari and P. Aimar, J. Membr. Sci., 2004, 238, 177-190.

54 F. Pena-Pereira, A. Kloskowski and J. Namieśnik, Green Chem., 2015, 17, 3687-3705.

55 M. Tobiszewski, J. Namieśnik and F. Pena-Pereira, Green Chem., 2017, 19, 1034-1042.

56 European Chemicals Agency, Information on chemicals, https://echa.europa.eu/information-on-chemicals.

57 I. Garcia-Herrero, R. M. Cuéllar-Franca, V. M. EnríquezGutiérrez, M. Alvarez-Guerra, A. Irabien and A. Azapagic, ACS Sustainable Chem. Eng., 2016, 4, 2088-2097.

58 K. H. Mitschke, K. Hallenberger, O. Schlak and J. Kaulen, U.S. Pat., 6673955, 2004.

59 D. Cordell, J. O. Drangert and S. White, Glob. Environ. Change, 2009, 19, 292-305.

60 C. S. M. Pereira, V. M. T. M. Silva and A. E. Rodrigues, Green Chem., 2011, 13, 2658-2671.

61 J. Van Krieken, A. B. De Haan and J. Van Breugel, European Pat., 2956434, 2017.

62 R. Datta, S. P. Tsai, P. Bonsignore, S. H. Moon and J. R. Frank, FEMS Microbiol. Rev., 1995, 16, 221-231.

63 R. Datta and M. Henry, J. Chem. Technol. Biotechnol., 2006, 81, 1119-1129.

64 D. M. Alonso, S. G. Wettstein and J. A. Dumesic, Green Chem., 2013, 15, 584-595.

65 J. J. Bozell and G. R. Petersen, Green Chem., 2010, 12, 539554.

66 S. Kang, J. Fu and G. Zhang, Renewable Sustainable Energy Rev., 2018, 94, 340-362.

67 C. J. Clarke, W. C. Tu, O. Levers, A. Bröhl and J. P. Hallett, Chem. Rev., 2018, 118, 747-800.

68 U. Omoruyi, S. Page, J. Hallett and P. W. Miller, ChemSusChem, 2016, 9, 1-12.

69 Z. Zhang, ChemSusChem, 2016, 9, 156-171.

70 INRS, N-Methyl-2-pyrrolidone, http://www.inrs.fr/publications/bdd/fichetox/fiche.html?refINRS=FICHETOX_213.

71 Toxicology Data Network, Hazardous Substances Data Bank, https://toxnet.nlm.nih.gov/cgi-bin/sis/htmlgen?HSDB.

72 D. Bégin, S. Heng and M. Gérin, La substitution des solvants par le lactate d'éthyle, Institut de recherche Robert-Sauvé en santé et en sécurité du travail, Quebec, 2005.

73 ChemSpider, http://www.chemspider.com/. 
74 G. J. Cox and M. L. Dodds, Ind. Eng. Chem., 1933, 25, 967-968.

75 L. Lomba, C. Lafuente, M. García-Mardones, I. Gascón and B. Giner, J. Chem. Thermodyn., 2013, 65, 34-41.

76 D. M. Alonso, S. G. Wettstein and J. A. Dumesic, Green Chem., 2013, 15, 584-595.

77 I. T. Horváth, H. Mehdi, V. Fábos, L. Boda and L. T. Mika, Green Chem., 2008, 10, 238-242.

78 C. Y. Y. Wong, A. W. T. Choi, M. Y. Lui, B. Fridrich, A. K. Horváth, L. T. Mika and I. T. Horváth, Struct. Chem., 2017, 28, 423-429.

79 International Programme on Chemical Safety, Chemical Safety Information from Intergovernmental Organizations, http://www.inchem.org/.

80 C. T. Bowmer, R. N. Hooftman, A. O. Hanstveit, P. W. M. Venderbosch and N. Van der Hoeven, Chemosphere, 1998, 37, 1317-1333.

81 The Organisation for Economic Co-operation and Development, Triethyl phosphate, http://www.inchem.org/ documents/sids/sids/78400.pdf.
82 J. Sherwood, A. Constantinou, L. Moity, C. R. McElroy, T. J. Farmer, T. Duncan and J. H. Clark, Chem. Commun., 2014, 50, 9650-9652.

83 M. A. Rasool and I. F. J. Vankelecom, Green Chem., 2019, 21, 1054-1064.

84 J. Puls, S. A. Wilson, D. Hölter and J. Polym, Environ., 2011, 19, 152-165.

85 A. F. M. Barton, Pure Appl. Chem., 1985, 57, 905-912.

86 M. Weng and J. Appl, Polym. Sci., 2017, 134, 44621.

87 R. Wiśniewski, E. Śmieszek and E. Kamińska, Prog. Org. Coat., 1995, 26, 265-274.

88 C. Cabassud, C. Anselme, J. L. Bersillon and P. Aptel, Filtr. Sep., 1991, 28, 194-198.

89 M. Meireles, A. Bessieres, I. Rogissart, P. Aimar and V. Sanchez, J. Membr. Sci., 1995, 103, 105-115.

90 H. Strathmann and K. Kock, Desalination, 1977, 21, 241255.

91 I. Cabasso, E. Klein and J. K. Smith, J. Appl. Polym. Sci., 1976, 20, 2377-2394. 